\title{
AKTIVITAS ANTIOKSIDAN MADUTERNAKAN DAN MADU KELENGKENG SEBAGAI PENGOBATAN ALAMI
}

\author{
PutuLakustiniCahyaningrum \\ Program StudiKesehatanAyurweda, Fakultas Kesehatan \\ Universitas Hindu Indonesia \\ E-mail :putulakustinicahyaningrum@gmail.com
}

\begin{abstract}
Abstrak
Dalam madu terdapat sumber kesehatan yang sangat luar biasa dan sangat bermanfaat untuk berbagai bentuk pengobatan yang alami. Penelitianinibertujuanuntukmengetahuiaktivitasantioksidandariduajenismadu yang berbedayaitumaduternakandanmadukelengkengdenganmenggunakanmetode DPPH.Dalam penelitian ini, penentuan aktivitas antiradikal bebas pada madu ternakan dan madu kelengkeng dilakukan secara langsung tanpa ada pemisahan dan pemurnian senyawa sehingga aktivitas antiradikal bebas yang dihasilkan tidak hanya dihasilkan oleh satu senyawa (misalnya karoten) melainkan hasil kerja sama senyawa-senyawa antioksidan yang terdapat pada madu. Dari hasilpenelitiandiperolehhasilbahwarata-rata persentase peredaman absorbansi DPPH madu ternakansebesar69,37 \% sedangkan madu kelengkeng 82,10\% sehingga persentase peredaman absorbansi DPPH yang paling besar terdapat pada madukelengkeng. Hal ini membuktikan bahwa madu dengan jenis bunga yang berbeda memiliki aktivitas antiradikal bebas berbeda pula. Perbedaan ini disebabkan karena sumber nektar kedua madu tersebut berbeda sehingga komposisi senyawanya juga berbeda. Nilai aktivitas antiradikal bebas yang tinggi pada madu, merupakan hasil kerjasama oleh beberapa senyawa antioksidan seperti flavonoid, vitamin E, vitamin C, beta karoten, asam fenolik dan lain sebagainya.
\end{abstract}

Kata Kunci :Maduternakan, madukelengkengdanaktivitasantioksidan

\begin{abstract}
In honey there is a source of health that is very extraordinary and very useful for various forms of natural treatment. This study aims to determine the antioxidant activity of two different types of honey, namely honey and kelengkeng honey using the DPPH method. In this study, the determination of free antiradical activity on honey and kelengkeng honey was carried out directly without any separation and purification of compounds so that the free antiradical activity produced was not only produced by one compound (eg carotene) but rather the collaboration of antioxidant compounds found in honey. From the results of the study, it was found that the average reduction of absorbed DPPH honey absorbance was $69.37 \%$ while the longan honey was $82.10 \%$ so that the greatest percentage of DPPH absorbance was found in longan honey. This proves that honey with different types of flowers has different free-radical activities. This difference is caused by the different nectar sources of the two honey so that the composition of the compounds is also different. The high value of free antiradical activity in honey is the result of cooperation by several antioxidant compounds such as flavonoids, vitamin $E$, vitamin $C$, beta carotene, phenolic acids and so on.
\end{abstract}

Keywords: Spiced honey, longan honey and antioxidant activity

\section{Pendahuluan}

Tubuh kita memerlukan suatu substansi penting yakni antioksidan yang dapat membantu melindungi tubuh dari serangan radikal bebas dengan meredam dampak negatif senyawa ini. Namun, hal ini tergantung terhadap pola hidup dan pola makan kita yang harus benar. Konsumsi antioksidan yang memadai dapat mengurangi terjadinya berbagai penyakit seperti kanker, kardiovaskuler,katarak, masalah pencernaan serta penyakit degeneratif lain (Kumalaningsih,2007).

Antioksidan merupakan suatu substansi yang pada konsentrasi kecil secara signifikan mampu menghambat atau mencegah oksidasi pada substrat yang disebabkan oleh radikal bebas. Senyawa antioksidan diantaranya adalah asam fenolik, 
flavonoid, $\beta$-karoten, vitamin $\mathrm{E}$, vitamin $\mathrm{C}$, asam urat, bilirubin, dan albumin. Zat-zat gizi mineral seperti mangan, seng, tembaga dan selenium (Se) juga berperan sebagai antioksidan. Selain dalam makanan, ternyata zat-zat tersebut juga terdapat dalam madu (Nainggolan, 1992).

Madu adalah cairan manis yang berasal dari nektar tanaman yang diproses oleh lebah pekerja menjadi madu dan tersimpan dalam sel-sel sarang lebah. Berbagai kelebihan madu sebagai makanan bernutrient tinggi sudah diketahui sejak zaman dahulu.Madu memang merupakan bahan konsumsi yang sangat baik untuk mempertahankan kesehatan dan stamina jasmani (Purbaya2002). Mineralnya diperlukan tubuh agar tetap segar, vitaminnya berperan dalam metabolisme protein dan mencegah penyakit kulit seperti eksim dan herpes. Kandungan fruktosa madu berperan dalam mempercepat proses oksidasi alkohol pada hati, sehingga dapat membantu menanggulangi kerusakan hati pada peminum minuman beralkohol.

Madu merupakan produk alamyang dihasilkan oleh lebah karena mengandung nutrisi yang baik. Beberapa kandungan gizi dalam madu antara lain asam amino, karbohidrat, protein, dan beberapa jenis vitamin serta mineral (Suriawiria, 2000).Kandungan nutrisi dalam madu yang berfungsi sebagai antioksidan adalah vitamin $\mathrm{C}$, asam organik, enzim, asam fenolik,dan beta karoten. Vitamin A dan vitamin $\mathrm{E}$ juga merupakan salah satu vitamin antioksidan esensial yang utama. Dengan demikian pada madu terdapat banyak nutrisi yang berfungsi sebagai antioksidan dan semua senyawa tersebut bekerjasama dalam melindungi sel normal dan menetralisir radikal bebas. Madu berasal dari nektar yang diolah lebah untuk dijadikan sebagai pakan yang disimpan dalam sarang.Nektar adalah suatu senyawa kompleks yang dihasilkan oleh kelenjar "necterifier" tanaman dalam bentuk larutan gula yang bervariasi. Komponen utama dari nektar adalah sukrosa, fruktosa, dan glukosa serta zat-zat gula lainnya seperti maltosa, melibiosa, rafinosa, dan turunan karbohidrat lainnya (Suranto, 2007).

Berdasarkan hasil penelitian tentang aktivitas antioksidan yang telah diteliti pada madu floral Australia dari jenis bunga yang berbeda yaitu Yapunyah, Leatherwood dan Salvation Jane menunjukkan bahwa madu dari jenis bunga yang berbeda memiliki aktivitas antioksidan yang berbeda pula, seperti pada madu Yapunyah aktivitas antioksidannya sebesar 1258,28 $\mu \mathrm{g} / 100 \mathrm{~g}$ madu sedangkan untuk madu Leatherwood adalah 2967,8 $\mu \mathrm{g} / 100 \mathrm{~g}$ madu dan salvation Jane $1139,2 \mu \mathrm{g} / 100 \mathrm{~g}$ madu (Bruce,2005).

Madu ternakan adalah madu yang dihasilkan melaluiternaklebah di lokasiperkebunan Indonesia dengancaraberpindah-pindahmengikutimusimbunga. Sedangkan Madu kelengkeng berasal dari madu ternak yang dihasilkan dari jenis nektar bunga buah kelengkeng, sebagai makanan lebah madu yang dibudidayakan di area hutan yang didominasi oleh pohon buah kelengkeng. Madu kelengkeng ini memiliki aroma khas seperti buah kelengkeng yang manis yang tidak dimiliki oleh jenis-jenis madulainnya.

Khasiat madu yang beragam berasal dari kandungan kimianya. Ada berbagai jenis enzim seperti diastase, invertase, katalase, peroksidase dan lipase yang membantu proses pencernaan. Sejumlah asam amino seperti asam malat, tartarat, sitrat, laktat, yang berperan dalam metabolisme. Dalam madu juga terdapat mineral dan bentuk garam-garamnya yang diperlukan tubuh agar tetap segar serta adanya vitamin yang berperan dalam metabolisme protein dan mencegah penyakit kulit (Nainggolan, 1992).

Beberapainformasitentangnilaiaktivitasa ntioksidanmaduternakandanmadukelengkengbelumba nyakdilaporkan.Olehkarenaitu,

padapenelitianinidilakukanuntukmengetahuiaktivitas antioksidanpadamadu yang adadipasaranyaitumaduternakandanmadukelengkeng denganmenggunakanmetodeDPPHsecaraspektrofoto metri UV-Vis.

\section{MetodePenelitian}

Rancangan penelitian ini adalah deskriptif eksploratif yaitu menentukan besarnya aktivitas antioksidan pada madu Indonesia dari jenisbungacampuranyaitumaduternakandan bunga Madu Kelengkeng. Aktivitas antiradikal bebas ditentukan dengan menggunakan metode DPPH secara spektrofotometri UV-Vis dan pencatatan absorbansi dilakukan pada panjang gelombang 497 $\mathrm{nm}, 517 \mathrm{~nm}$, dan $537 \mathrm{~nm}$.

\section{a. BahanPenelitian}

Bahan-bahan yang digunakan dalam penelitian antara lain : Madu ternakan, madukelengkeng, aquades, kristal difenilpikril hidrazil (DPPH) dan metanol.

\section{b. Alat Penelitian}

Alat-alat yang digunakan dalam penelitian antara lain : seperangkat alat gelas, neraca analitik, labu ukur $10 \mathrm{~mL}$, pipet ukur $1 \mathrm{~mL}$ dan $2 \mathrm{~mL}$, 
stop watch, spektrofotometer UV-Vis (UV - 1601 Shimadzu).

\section{c. Tempat Penelitian}

Penelitian dilakukan di Laboratorium Klinik Fakultas Kesehatan Program Studi Kesehatan Ayurweda. Analisis Spektrofotometri UV-Vis dilakukan di Laboratorium Program Studi Biologi Fakultas Matematika dan Ilmu Pengetahuan Alam Universitas Hindu Indonesia.

\section{d. Prosedur Penelitian}

1) Penyiapan bahan

Sampel madu yang digunakan dalam penelitian berasal dari hasil peternakan lebah Multi Sari danNusantara, dimana kualitas madunya sudah memenuhi Standar Industri Indonesia (SII).

\section{2) Penentuan Aktivitas Antiradikal Bebas secara Spektroskopi}

Penentuan aktivitas antiradikal bebas ini dikerjakan dengan beberapa tahapan sebagai berikut :

1. Pengenceran Sampel Madu

Sebanyak 0,08 gram madu yang diperoleh diencerkan dengan metanol pada labu ukur $10 \mathrm{~mL}$ sehingga kadarnya 8000 ppm

2. Pembuatan Larutan DPPH

Kristal DPPH ditimbang sebanyak 0,004 gram kemudian dilarutkan dalam metanol dengan menggunakan labu ukur teapat $100 \mathrm{ml}$ sehingga kadarnya 0,004 $\%(\mathrm{~b} / \mathrm{v})$

3. Pengujian Aktivitas Antiradikal Bebas (Djatmoko, 1998)

a. Pengukuran Absorbansi DPPH

Spektra absorbansi DPPH diukur pada panjang gelombang ( $\lambda) 400-700 \mathrm{~nm}$ (sinar tampak). Larutan blanko yang digunakan adalah metanol. Pencatatan dilakukan terhadap absorbansi pada panjang gelombang $497 \mathrm{~nm}, 517 \mathrm{~nm}$ dan $537 \mathrm{~nm}$ untuk DPPH.

b. Pengukuran Aktivitas

Antiradikal Bebas Larutan Standar beta karoten 100 ppm Sejumlah $1 \mathrm{~mL}$ larutan standar 100 ppm dimasukkan kedalam kuvet lalu ditambahkan ke dalamnya $2 \mathrm{~mL}$ larutan $\mathrm{DPPH}$ $0,004 \%$. Campuran tersebut kemudian diaduk rata dengan menggunakan pipet. Pada menit ke-5 dan ke-60 setelah reaksi berlangsung, dilakukan pencatatan absorbansi pada panjang gelombang $497 \mathrm{~nm}$, $517 \mathrm{~nm}$, dan $537 \mathrm{~nm}$.

c. Pengukuran Absorbans Sampel MaduTernakandanKapukKelen gkeng

Sejumlah $1 \mathrm{~mL}$ sampel madu dimasukkan kedalam kuvet lalu ditambahkan ke dalamnya $\mathrm{mL}$ larutan DPPH 0,004 \%. Campuran tersebut kemudian diaduk rata dengan menggunakan pipet. Pada menit ke-5 dan ke-60 setelah reaksi berlangsung, dilakukan pencatatan absorbansi pada panjang gelombang $497 \mathrm{~nm}$, $517 \mathrm{~nm}$, dan $537 \mathrm{~nm}$.

\section{HasildanPembahasan}

\subsection{Proses Pembuatan Madu}

Madu adalah zat manis alami yang dihasilkan lebah dengan bahan baku nektar bunga. Diperlukan dua faktor untuk menghasilkan madu. Pertama, bunga yang nektarnya merupakan bahan baku pembuatan madu. Kedua, serangga yaitu lebah yang merupakan tenaga ahlinya. Nektar adalah senyawa kompleks yang dihasilkan kelenjar tanaman dalam bentuk larutan gula. Perubahan nektar menjadi madu dimulai ketika lebah pekerja membawa nektar ke sarangnya. Nektar yang berhasil dibawa pulang diberikan kepada lebah pekerja lainnya untuk dicampur dengan air liur dan dihilangkan airnya (Sarwono,B.,2001).

Madu murni adalah cairan nektar bunga yang dihisap oleh lebah madu kedalam kantong madu didalam tubuhnya. Nektar bunga yang telah dihisap diolah dalam tubuh lebah dengan dicampur enzim tertentu kemudian dikeluarkan kembali ketempat penyimpanan madu di sarang lebah. Madu bermula dari nektar yang terdapat dalam bungabungaan pada tumbuhan. Lebah menyedot nektar tersebut dengan menggunakan lidah panjangnya yang berbentuk seperti tabung. Cairan manis tersebut kemudian disimpan dalam kantung madu dalam tubuh lebah dan kemudian mencampurnya dengan 
bahan-bahan kimia tertentu didalamnya. Ketika lebah kembali ke sarang, campuran dan bahan kimia tadi disimpan dalam sel dan setelah masak campuran tadi berubah menjadi madu. Mereka umumnya tertarik dengan warna dan juga bau bunga tersebut, bunga warna kuning dan biru lebih disukai oleh lebah.

Dalampenelitianiniduajenismadu yang digunakanadalahSampel madu yang berasal dari hasil peternakan lebah multi sari dan Nusantara, dimana kualitas madunya sudah memenuhi Standar Industri Indonesia

(SII).Gambarmaduternakandanmadukelengkeng yang digunakandalampenelitianiniadalahsesuaigambar di bawah :

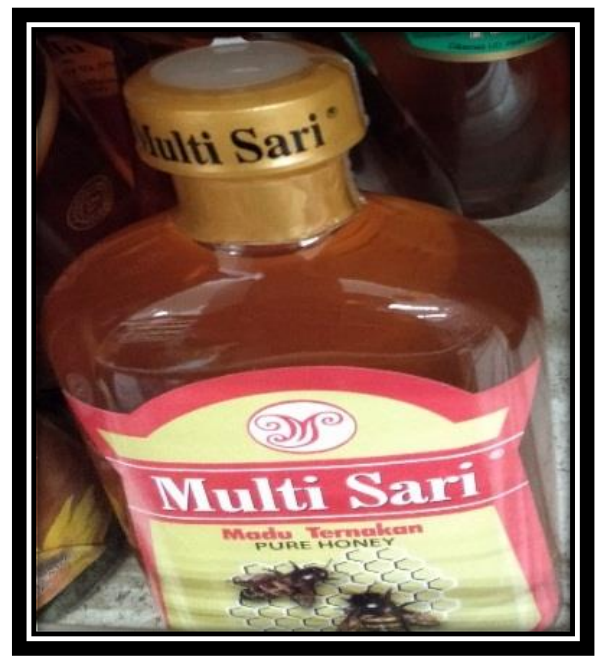

Gambar 1a.MaduTernakan

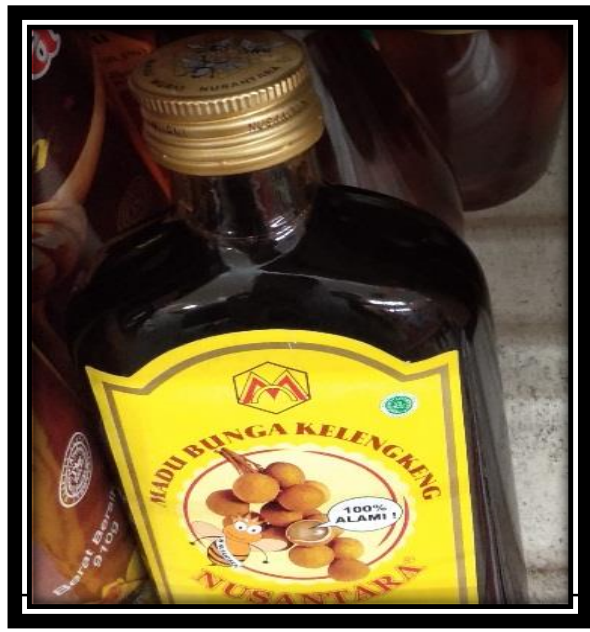

E-Jurnal Widya Kesehatan, Volume 1, Nomor; 1, Mei 2019

\section{Gambar 1b.MaduKelengkeng}

\subsection{UjiAntioksidanMaduTernakandanMadu Kelengkeng}

Madu mengandung berbagai jenis senyawa yang dapat berperan sebagai antiradikal bebas seperti flavonoid, asam fenolik, beta karoten, vitamin C dan vitamin E. Dalam penelitian ini, penentuan aktivitas antiradikal bebas pada madu ternakan dan madu kelengkeng dilakukan secara langsung tanpa ada pemisahan dan pemurnian senyawa sehingga aktivitas antiradikal bebas yang dihasilkan tidak hanya dihasilkan oleh satu senyawa (misalnya karoten) melainkan hasil kerja sama senyawasenyawa antioksidan yang terdapat pada madu.

Dari

hasilujianalisisantioksidanmenggunakanmetode

DPPH secaraspektrofotometri UV-

Vis.diketahuibahwakeduajenismaduyaitumaduternak andanmadukelengkengmemilikinilaiaktivitasantiradik albebas yang berbedasesuaipadatabel 1 dibawahini :

Tabel 1. Hasil Aktivitas Antiradikal Bebas Sampel Madu dan Standar

\begin{tabular}{|c|c|c|c|c|}
\hline \multirow[t]{2}{*}{ Sampel } & \multicolumn{2}{|c|}{$\begin{array}{c}\text { \% peredaman } \\
\text { absorbansi } \\
\text { DPPH }\end{array}$} & \multicolumn{2}{|c|}{ Rata-rata $\%$ peredaman } \\
\hline & $\begin{array}{c}5 \\
\text { menit }\end{array}$ & $\begin{array}{c}60 \\
\text { menit }\end{array}$ & 5 menit & 60 menit \\
\hline MTE 1 & $40 \%$ & $\begin{array}{c}69,86 \\
\%\end{array}$ & $\begin{array}{l}40 \% \pm \\
2,6650\end{array}$ & $\begin{array}{c}69,37 \% \\
\pm 0,4273\end{array}$ \\
\hline MTE 2 & $\begin{array}{c}42,67 \\
\%\end{array}$ & $\begin{array}{c}69,12 \\
\%\end{array}$ & & \\
\hline MTE 3 & $\begin{array}{c}37,34 \\
\%\end{array}$ & $\begin{array}{c}69,12 \\
\%\end{array}$ & & \\
\hline MKE1 & $\begin{array}{c}42,67 \\
\%\end{array}$ & $\begin{array}{c}70,59 \\
\%\end{array}$ & $\begin{array}{c}52 \% \\
\pm 8,3267\end{array}$ & $\begin{array}{c}82,10 \% \\
\pm 2,4239\end{array}$ \\
\hline MKE2 & $\begin{array}{c}58,67 \\
\%\end{array}$ & $\begin{array}{c}81,60 \\
\%\end{array}$ & & \\
\hline MKE3 & $\begin{array}{c}54,67 \\
\%\end{array}$ & $\begin{array}{c}94,12 \\
\%\end{array}$ & & \\
\hline $\begin{array}{l}\text { Standar } \\
\text { beta } \\
\text { karoten }\end{array}$ & $\begin{array}{c}26,67 \\
\%\end{array}$ & $\begin{array}{c}80,15 \\
\%\end{array}$ & $26,67 \%$ & $80,15 \%$ \\
\hline
\end{tabular}

Keterangan : MTE = Madu Ternakan $\quad$ MKE $=$ MaduKelengkeng

Berdasarkan Tabel 1 menunjukkan bahwa rata-rata persentase peredaman absorbansi DPPH madu ternakansebesar69,37 \% sedangkan madu 
kelengkeng 82,10\% sehingga persentase peredaman absorbansi DPPH yang paling besar terdapat pada madukelengkeng. Hal ini membuktikan bahwa madu dengan jenis bunga yang berbeda memiliki aktivitas antiradikal bebas berbeda pula. Hasil ini sesuai dengan hasil penelitian yang dilakukan pada madu floral Australia bahwa pada bunga yang berbeda memiliki aktivitas antiradikal bebas yang juga berbeda (Bruce, 2005). Perbedaan ini disebabkan karena sumber nektar kedua madu tersebut berbeda sehingga komposisi senyawanya juga berbeda. Pernyataan ini didukung oleh Suranto A, 2007 yang menyatakan bahwa tiap jenis madu memang memiliki efek antiradikal bebas yang berbeda-beda dimana jumlah dan kandungan antioksidannya sangat tergantung dari sumber nektarnya.

Hasil penelitian pada madu floral Australia, menunjukkan semakin gelap warna madu maka semakin tinggi aktivitas antioksidannya (Bruce, 2005). Hal ini sesuai dengan hasil penelitian yang telah dilakukan, di mana aktivitas antiradikal bebas yang lebih besar ditunjukkan oleh madu kelengkengyang berwarna lebih gelap.

Nilai aktivitas antiradikal bebas yang tinggi pada madu, merupakan hasil kerjasama oleh beberapa senyawa antioksidan (flavonoid, vitamin E, vitamin $\mathrm{C}$, beta karoten, asam fenolik dan lain sebagainya). Hal ini didukung oleh penelitian yang telah dilakukan pada madu floral Austalia, dimana senyawa antioksidan yang lebih berperan dalam menyumbangkan nilai aktivitas antiradikal bebas pada madu Australia adalah senyawa flavonoid dan asam fenolik (Bruce, 2005).

MenurutSuriawiria (2000) bahwaKandungan nutrisi dalam madu yang berfungsi sebagai antioksidan adalah vitamin $\mathrm{C}$, asam organik, enzim, asam fenolik,dan beta karoten. Vitamin A dan vitamin $\mathrm{E}$ juga merupakan salah satu vitamin antioksidan esensial yang utama. Dengan demikian pada madu tedapat banyak nutrisi yang berfungsi sebagai antioksidan dan semua senyawa tersebut bekerjasama dalam melindungi sel normal dan menetralisir radikal bebas. Faktor kualitas maupun kuantitas madu sangat dipengaruhi oleh jenis bunga dan jenis lebahnya. Rasa dan jenis madu ditentukan oleh jenis bunga sebagai makanan lebah tersebut. Hasil madu sangat dipengaruhi oleh cuaca dan iklim dimana bunga yang dihisap oleh lebah tersebut berada.

Dari hasil penelitian terbaru ternyata zat-zat atau senyawa yang ada di dalam madu sangat kompleks yaitu mencapai 181 jenis. Khasiat madu telah dikenal sejak jaman Mesir Kuno. Bangsa Mesir kuno memanfaatkan madu untuk mengobati luka bakar dan luka akibat tusukan benda tajam. Studi mengenai khasiat madu sebagai obat tidak pernah berhenti dilakukan ilmuwan di seluruh penjuru dunia. Semakin lama semakin banyak fakta yang mengungkap peran penting madu sebagai obat, sebagai antibakteri, atau sebagai pengobatan alami.

Kadar pH madu biasanya bersar 3,2 sampai 4,5 tingkat $\mathrm{pH}$ yang relatif asam ini mencegah pertumbuhan antibakteri. Hal ini disebabkan $\mathrm{pH}$ madu berbeda pada kisaran 3,2 - 4,5 keasaman madu adalah faktor signifikan madu bersifat antibakteri. Sifat antibakteri madu membantu mengatasi infeksi pada luka. Madu juga merangsang tumbuhnya jaringan baru, mempercepat penyembuhan dan mengurangi timbulnya perut atau bekas luka pada kulit.

Antioksidan yang terkandung dalam madu dapat mengurangi kerusakan usus pada peradangan usus besar. Lebih jauh lagi sejumlah studi mengungkapkan madu berperan efektif dalam meningkatkan populasi bakteri probiotik didalam usus sehingga meningkatkan sistem kekebalan tubuh, memperbaiki pencernaan, berkadar kolesterol rendah dan mencegah kanker usus. Khasiat setiap jenis madu bisa saja berbeda tetapi semua jenis madu pasti mengandung antioksidan, seperti vitamin $\mathrm{E}$ dan Vitamin C yang kadarnya sama.

\section{Simpulandan Saran}

\section{Simpulan}

Berdasarkan hasil penelitian yang telah dilakukan, maka dapat disimpulkan sebagai berikut :

1. Madu dengan jenis bunga yang berbeda yaitu madu ternakan dan madu Kelengkeng memiliki aktivitas antiradikal bebas yang berbeda. Di mana aktivitas antiradikal bebas pada madu kelengkeng lebih besar yaitu $82,10 \%$ dibandingkan dengan madu ternakan yaitu $69,37 \%$.

2. Nilai aktivitas antiradikal bebas yang tinggi pada madu kelengkeng merupakan hasil kerjasama oleh beberapa senyawa antioksidan seperti flavonoid, vitamin $\mathrm{E}$, vitamin $\mathrm{C}$, beta karoten, asam fenolik dan lain sebagainya.

\section{Saran}

Saran dari penelitian ini adalah perlu dilakukan penelitian lebih lanjut tentang senyawa antioksidan yang terdapat pada madu ternakan dan madu kelengkeng yang memberi sumbangan 
terhadap aktivitas antiradikal bebas dengan menggunakan teknik isolasi senyawa bahan alam.

\section{DAFTAR PUSTAKA}

Bruce, R D'Arcy. 2005. Antioxidants in Australian Floral Honeys Identification of HealthEnhancing nutrient Components. RIRDC Publication

Djatmiko., Santosa.,\& Wahyo. 1998. Seminar Nasional tumbuhan Obat XII, Fakultas farmasi Unair, Surabay

Kumalaningsih, Sri. 2007. AntioksidanAlami :PenangkalRadikalBebas. Surabaya :TrubusAgrisarana
Nainggolan, S. 1992. PemeriksaanKandungan Kimia MadudariHasilPerolehanLebahPemeliharaa ndanLebahHutan.LembagaPenelitianUniversi tas Sumatera Utara. Medan.

$\begin{array}{llll}\text { Purbaya, } & \text { J. } & \text { R. }\end{array}$ MengenaldanMemanfaatkanKhasiatMaduAla $m i$.Bandung :PenerbitPinonir Jaya

Suranto, A. 2007.KhasiatdanManfaatMadu Herbal. Jakarta: Agro Media Pustaka

Suriawiria, H. U. 2000. Madu untuk Kesehatan, Kebugaran, dan Kecantikan. Jakarta: Papas Sinar Sinanti.

Sarwono B. 2001. Kiat Mengatasi Permasalahan Praktis Lebah Madu. Cetakan Pertama. Jakarta : PT . Agro Media Pustaka. 